\title{
Intraspecies Regulation of Ribonucleolytic Activity ${ }^{\dagger}$
}

\author{
R. Jeremy Johnson $\ddagger$, Luke D. Lavis $§$, and Ronald T. Raines ${ }^{\ddagger},{ }^{*}{ }^{*}$ \\ $\$$ Department of Biochemistry, University of Wisconsin-Madison, Madison, Wisconsin 53706
}

$\S$ Department of Chemistry, University of Wisconsin-Madison, Madison, Wisconsin 53706

\section{Abstract}

The evolutionary rate of proteins involved in obligate protein-protein interactions is slower and the degree of co-evolution higher than that for non-obligate protein-protein interactions. The coevolution of the proteins involved in certain non-obligate interactions is, however, essential to cell survival. To gain insight into the co-evolution of one such non-obligate protein pair, the cytosolic ribonuclease inhibitor (RI) proteins and secretory pancreatic-type ribonucleases from cow (Bos taurus) and human (Homo sapiens) were produced in Escherichia coli and purified, and their physicochemical properties were analyzed. The two intraspecies complexes were found to be extremely tight (bovine $K_{\mathrm{d}}=0.69 \mathrm{fM}$; human $K_{\mathrm{d}}=0.34 \mathrm{fM}$ ). Human RI binds to its cognate ribonuclease (RNase 1) with 100-fold greater affinity than to the bovine homologue (RNase A). In contrast, bovine RI binds to RNase 1 and RNase A with nearly equal affinity. This broader specificity is consistent with there being more pancreatic-type ribonucleases in cows (20) than humans (13). Human RI (32 cysteine residues) also has 4-fold less resistance to oxidation by hydrogen peroxide than does bovine RI ( 29 cysteine residues). This decreased oxidative stability of human RI, which is caused largely by Cys74, implies a larger role for human RI as an antioxidant. The conformational and oxidative stabilities of both RIs increase upon complex formation with ribonucleases. Thus, RI has evolved to maintain its inhibition of invading ribonucleases, even when confronted with extreme environmental stress. That role appears to take precedence over its role in mediating oxidative damage.

The discovery of extensive protein-protein interaction networks has informed investigations of protein evolution (1-3). For example, the rate of evolution within a protein-protein interaction network, has been found to depend on the number of binding partners, the concentration of each protein, and the evolutionary age of the proteins (4-10). These relationships extend to subclasses of interactions, as obligate protein-protein interactions, which are defined as interactions necessary for the stability of an individual protein (11), evolve at a slower rate and show a greater degree of co-evolution than do non-obligate interactions, which are interactions between proteins that can remain stable independently (7). Nonetheless, the co-evolution of certain non-obligate protein-protein interactions, such as particular receptor-ligand and enzyme-inhibitor interactions, can be essential for cell survival (11). To understand the co-evolution of such a non-obligate pair, we have investigated the complex formed between the cytosolic ribonuclease inhibitor protein $\left(\mathrm{RI}^{1}\right)$ and secretory pancreatictype ribonucleases, as failure to inhibit the enzymatic activity of an invading ribonuclease can lead to cell death (12-15).

\footnotetext{
${ }^{\dagger}$ This work was supported by Grant CA73808 (NIH). R.J.J. and L.D.L. were supported by Biotechnology Training grant 08349 (NIH). L.D.L. was also supported by an ACS Division of Organic Chemistry Fellowship, sponsored by the Genentech Foundation. The Biophysics Instrumentation Facility was established with grants BIR-9512577 (NSF) and RR13790 (NIH). The W.M. Keck Center for Chemical Genomics was established by a grant from the W.M. Keck Foundation

*To whom correspondence should be addressed: Department of Biochemistry, University of Wisconsin-Madison, 433 Babcock Drive, Madison, WI 53706-1544. Telephone: 608-262-8588. Fax: 608-262-3453. E-mail: raines@biochem.wisc.edu.
} 
The ribonuclease A superfamily is comprised of homologues of bovine pancreatic ribonuclease (RNase A (12); 124 residues; EC 3.1.27.5), which are found only in vertebrates (16-20). The superfamily has expanded rapidly $(21,22)$, with only three members in fish (Danio rerio) (23) and chicken (Gallus gallus) (21,24), but 20 and 13 members in cow (Bos taurus) (22) and human (Homo sapiens) (21), respectively. The lethal enzymatic activity of ribonucleases is modulated by RIs $(25,26)$, which binds to some members of the ribonuclease A superfamily with affinities in the femtomolar range $(27,28)$. RI is able to exert this affinity using its large concave surface area (28-30), even though the sequence identity among superfamily members is $<30 \%(26,28)$. RI evolved rapidly by exon duplication around the time of ribonuclease expansion (31), suggesting co-evolution of the protein families, but this direct relationship has not been demonstrated conclusively (26).

Although RNase A is perhaps the most studied of all enzymes (12), little is known about its cognate inhibitor, bovine RI (bRI; 456 residues). In contrast, human RI (hRI; 460 residues) is known to bind to ribonucleases from such evolutionary distant organisms as fish, chickens, and cows $(23,24,29,30)$. Yet, we demonstrated recently that the affinity of hRI for RNase A is significantly lower than that for human pancreatic ribonuclease (RNase 1; 128 residues), suggesting a co-evolution of affinity between RI and its species-specific ribonucleases (28).

Here, we report on the heterologous production, purification, and characterization of bRI. We find that bRI forms a highly stable complex with both RNase A and RNase 1. We also find that $b R I$ is stabilized to both thermal and oxidative stress upon ribonuclease binding. These and other observations provide insight into the molecular evolution and biological imperatives of an extraordinary non-obligate protein-protein interaction.

\section{EXPERIMENTAL PROCEDURES}

\section{General}

Escherichia coli BL21(DE3) cells and the plasmid pET22b(+) were from Novagen (Madison, WI). DNA oligonucleotides for PCR, sequencing, and mutagenesis were from Integrated DNA Technologies (Coralville, IA). Protein purification columns were from GE Healthcare (Piscataway, NJ). MES buffer (Sigma Chemical, St. Louis, MO) was purified by anionexchange chromatography to remove trace amounts of oligomeric vinylsulfonic acid (32). Restriction and PCR enzymes were from Promega (Madison, WI). All other chemicals were of commercial grade or better, and were used without further purification.

Terrific broth (TB) contained (in $1.00 \mathrm{~L})$ tryptone $(12 \mathrm{~g})$, yeast extract $(24 \mathrm{~g})$, glycerol $(4 \mathrm{~mL})$, $\mathrm{KH}_{2} \mathrm{PO}_{4}(2.31 \mathrm{~g})$, and $\mathrm{K}_{2} \mathrm{HPO}_{4}(12.54 \mathrm{~g})$. Phosphate-buffered saline (PBS), $\mathrm{pH} 7.4$, contained (in $1.00 \mathrm{~L}) \mathrm{NaCl}(8.0 \mathrm{~g}), \mathrm{KCl}(2.0 \mathrm{~g}), \mathrm{Na}_{2} \mathrm{HPO}_{4} \cdot 7 \mathrm{H}_{2} \mathrm{O}(1.15 \mathrm{~g}), \mathrm{KH}_{2} \mathrm{PO}_{4}(2.0 \mathrm{~g})$, and $\mathrm{NaN}_{3}$ $(0.10 \mathrm{~g})$.

Circular dichroism (CD) data were collected with a model 62A DS CD spectrometer (Aviv, Lakewood, NJ) equipped with a temperature controller. The molecular mass of each RI and ribonuclease was determined by matrix-assisted laser desorption/ionization-time-of-flight (MALDI-TOF) mass spectrometry using a Voyager-DE-PRO Biospectrometry Workstation (Applied Biosystems, Foster City, CA). CD and MALDI-TOF mass spectrometry experiments were performed at the campus Biophysics Instrumentation Facility. The fluorescence intensity in microtiter plates was recorded in a Perkin-Elmer EnVision 2100 plate reader equipped with

\footnotetext{
${ }^{1}$ Abbreviations: BSA, bovine serum albumin; bRI, bovine ribonuclease inhibitor; $\mathrm{CD}$, circular dichroism; cDNA, complementary DNA; DTT, dithiothreitol; HEPES, $N$-cyclohexyl-2-aminoethanesulfonic acid; hRI, human ribonuclease inhibitor; LRR, leucine-rich repeats; MALDI-TOF, matrix-assisted laser desorption/ionization-time-of-flight; MES, 2-( $N$-morpholino)ethanesulfonic acid; PBS, phosphatebuffered saline; PCR, polymerase chain reaction; PDB, Protein Data Bank; RI, ribonuclease inhibitor; RNase A, bovine pancreatic ribonuclease; RNase 1, human pancreatic ribonuclease.
} 
an FITC filter set (excitation: $485 \mathrm{~nm}$ with a $14-\mathrm{nm}$ bandwidth; emission: $535 \mathrm{~nm}$ with a 25nm bandwidth; dichroic mirror cutoff: $505 \mathrm{~nm}$ ) in the campus W.M. Keck Center for Chemical Genomics.

\section{RI cDNA Cloning and Protein Preparation}

The sequence of bRI was identified by its hypothetical annotation in the GenBank database (http://www.ncbi.nlm.nih.gov/Genbank/index.html). bRI (gi:78369509) was labeled as "Bos taurus similar to ribonuclease inhibitor". Its amino-acid sequence had $74 \%$ identity to that of hRI (Figure S-1) (28). DNA primers 5'CTTTTCATATGAAGCTGGACATCCAGTGTGAGCAGCTCAGCG-3' and 5'CTTTTTAAGCTTTCAGGAGATGATCCGCAGGCCAGGCTTGCTCTC-3' were designed to amplify the cDNA encoding bRI and to incorporate NdeI and HindIII restriction sites at the $5^{\prime}$ and $3^{\prime}$ ends, respectively. cDNA encoding bRI was amplified by PCR from a bovine brain cDNA library (BioChain Institute, Hayward, CA). The PCR product was inserted into plasmid pCR4-TOPO (Invitrogen, Carlsbad, CA), and sequence analysis was performed to ensure proper amplification.

\section{RI Production and Purification}

The cDNA encoding bRI was inserted into plasmid pET22b $(+)$ for protein production. A plasmid that encodes $\mathrm{hRI}(28,33)$ was used to create cysteine-residue variants of $\mathrm{hRI}$ using the Quikchange site-directed mutagenesis kit (Stratagene, La Jolla, CA). Both wild-type RI proteins and variants of hRI were produced and purified by using the procedure described previously $(34,28)$.

\section{Ribonuclease Production, Purification, and Labeling}

RNase 1, RNase A, and their free cysteine residue variants were purified from inclusion bodies using the oxidative folding procedure described previously $(28,33)$. Plasmids containing DNA encoding wild-type RNase 1 and RNase A were used to create variants with a free cysteine residue at position $19(28,35)$ using the Quikchange site-directed mutagenesis kit (Stratagene, La Jolla, CA). Position 19 was chosen as the attachment site, because attachment of fluorescent groups at this position does not have a detectable effect on the ribonucleolytic activity or RIaffinity of the resulting variants $(25,36)$. Variants of RNase 1 and RNase A with a free cysteine were initially protected by reaction with 5,5'-dithio-bis(2-nitrobenzoic acid) $(28,35,37)$.

Immediately before fluorophore attachment, protected variants were deprotected by using a 3fold molar excess of dithiothreitol (DTT) and desalted by chromatography using a PD-10 desalting column (Amersham Biosciences, Piscataway, NJ). Deprotected ribonuclease variants were reacted for $4-6 \mathrm{~h}$ at $25^{\circ} \mathrm{C}$ with a 10-fold molar excess of $2^{\prime}, 7^{\prime}$-diethylfluorescein-5iodoacetamide, which was synthesized as described previously (38). Diethylfluoresceinlabeled ribonucleases were purified by chromatography using a HiTrap SP FF column.

\section{Dissociation Rate}

The dissociation rates of the RI-ribonuclease complexes were determined by using a procedure described previously (28). Briefly, diethylfluorescein-labeled ribonuclease (100 nM) in PBS containing tris(2-carboxyethyl)phosphine $(0.10 \mathrm{mM})$ and bovine serum albumin (BSA, 0.10 $\mathrm{mg} / \mathrm{mL}$; Sigma Chemical) was added to a 96-well microtiter plate, and the initial fluorescence was measured. RI was then added at equimolar concentrations $(100 \mathrm{nM})$ and incubated with a labeled ribonuclease at $25^{\circ} \mathrm{C}$ for $5 \mathrm{~min}$. A 50 -fold molar excess of human angiogenin $(5 \mu \mathrm{M})$ (purified as described previously (39)) was added to scavenge dissociated RI, and the change in fluorescence was measured at various time points. To ensure that the stability of the proteins was maintained over the extended duration of the experiment, additional data points were monitored under the same conditions, only without the addition of angiogenin. Data are the 
mean $( \pm \mathrm{SE})$ of six replicates standardized for the mean fluorescence of six replicates of a rhodamine 110 standard $(10 \mathrm{nM})$ and normalized for the fluorescence before RI addition $\left(F_{\infty}\right)$ and for the maximum fluorescence change of the fully dissociated hRI-RNase A complex. Fluorescence data were fitted to eq 1 with the program GraphPad Prism 4.02 (GraphPad Software, San Diego, CA) to determine the dissociation rate $\left(k_{\mathrm{d}}\right)$, wherein $F_{0}$ is the fluorescence before the addition of angiogenin, and $F_{\infty}$ is the fluorescence before RI addition. Initial fluorescence data $(<4 \mathrm{~h})$ were not included in the analysis of RI-RNase 1 complexes, as they showed a rapid burst in fluorescence similar to that observed in previous dissociation rate determinations $(27,28)$. Initial fluorescence data was, however, included in the analysis of the RI-RNase A complexes, as the fluorescence change for their dissociation was greater than the initial burst.

$$
F=F_{0}+\left(F_{\infty}-F_{0}\right)\left(1-e^{k_{\mathrm{d}} t}\right)
$$

\section{Conformation and Conformational Stability}

CD spectroscopy was used to assess the secondary structural conformation of RI-ribonuclease complexes (40). Complexes between RI $(25 \mu \mathrm{M})$ and ribonuclease $(28 \mu \mathrm{M})$ were formed by incubation in PBS containing DTT $(2 \mathrm{mM})$ at $25^{\circ} \mathrm{C}$ for $30 \mathrm{~min}$. A slight molar excess of ribonuclease was added to ensure that all RI molecules were complexed with ribonuclease. The CD signal contributed by the excess ribonuclease was then masked by the higher CD signal from RI. Additionally, free ribonuclease $(28 \mu \mathrm{M})$ and free RI $(25 \mu \mathrm{M})$ were prepared for CD measurement using conditions identical to those used to prepare RI-ribonuclease complexes. $\mathrm{CD}$ spectra were acquired from 260 to $205 \mathrm{~nm}$ in 1-nm increments at $25^{\circ} \mathrm{C}$, and the background CD spectrum of PBS containing DTT $(2 \mathrm{mM})$ was subtracted from each spectrum. CD spectra are shown as the mean residue-weight ellipticity at each wavelength (41).

CD spectroscopy was also used to evaluate the conformational stability of the RI-ribonuclease complexes (40). The preparation of free RI, free ribonuclease, and RI-ribonuclease complexes was the same as for $\mathrm{CD}$ spectra determination. Protein solutions were heated from 25 to $75^{\circ}$ $\mathrm{C}$ in $2-^{\circ} \mathrm{C}$ increments. The change in molar ellipticity at $222 \mathrm{~nm}$ was measured after a 2 -min equilibration at each temperature. $\mathrm{CD}$ data at $222 \mathrm{~nm}$ were fitted to a two-state model with the program GraphPad Prism 4.02 to determine the values of $T_{\mathrm{m}}(42,43)$.

\section{Oxidative Stability}

The stability of RI and RI-ribonuclease complexes to oxidation by hydrogen peroxide $\left(\mathrm{H}_{2} \mathrm{O}_{2}\right)$ was assessed by using a method similar to that described previously (44), except that the decrease in the fluorescence of diethylfluorescein-labeled ribonuclease upon RI-binding was used to quantitate binding instead of indirectly following RI-binding through measurement of ribonucleolytic activity $(36,38)$. Immediately prior to assaying oxidative stability, purified RI was dialyzed for $16 \mathrm{~h}$ at $4{ }^{\circ} \mathrm{C}$ against $20 \mathrm{mM}$ HEPES- $\mathrm{HCl}$ buffer, $\mathrm{pH} 7.6$, containing $\mathrm{KCl}$ $(50 \mathrm{mM})$ and DTT $(200 \mu \mathrm{M})$, such that the final concentration of DTT in the $\mathrm{H}_{2} \mathrm{O}_{2}$ reactions was $\leq 50 \mu \mathrm{M}$. Fresh $\mathrm{H}_{2} \mathrm{O}_{2}$ (30\% v/v, Fisher Scientific, Fair Lawn, NJ or Sigma Chemical) was diluted to $2 \% \mathrm{v} / \mathrm{v}$ in $20 \mathrm{mM}$ HEPES-HCl buffer, $\mathrm{pH} 7.6$, containing $\mathrm{KCl}(50 \mu \mathrm{M})($ Buffer A). The $\mathrm{H}_{2} \mathrm{O}_{2}$ solution (2\% v/v) was then serially diluted (10 solutions of 56:100) with Buffer A (final range $\left.=1-0.003 \% \mathrm{v} / \mathrm{v} \mathrm{H}_{2} \mathrm{O}_{2}\right)$. Complexes were formed between $\mathrm{RI}(10 \mu \mathrm{M})$ and ribonuclease $(10 \mu \mathrm{M})$ in Buffer $\mathrm{A}$ and incubated for $15 \mathrm{~min}$ at $23{ }^{\circ} \mathrm{C}$ prior to $\mathrm{H}_{2} \mathrm{O}_{2}$ treatment. Free RI and ribonuclease were treated identically with the same volume of Buffer $\mathrm{A} . \mathrm{H}_{2} \mathrm{O}_{2}$ dilutions ( $5 \mu \mathrm{L})$ and RI, ribonuclease, or RI-ribonuclease complex ( $5 \mu \mathrm{L}$ of a $10 \mu \mathrm{M}$ solution) were added jointly to a 96-well PCR plate (Bio-Rad Laboratories, Hercules, CA). Plates were heated at $37^{\circ} \mathrm{C}$ for $30 \mathrm{~min}$ in a PTC-100 thermal cycler equipped with a heated lid (Bio-Rad Laboratories). After $30 \mathrm{~min}$, Buffer A (10 $\mu \mathrm{L})$ was added to RI-ribonuclease complex and ribonuclease wells, RNase 1 (10 $\mu \mathrm{L}$ of a $5 \mu \mathrm{M}$ solution) was added to hRI wells, and RNase 
A (10 $\mu \mathrm{L}$ of a $5 \mu \mathrm{M}$ solution) was added to bRI wells. Plates were incubated for an additional $5 \mathrm{~min}$ in the thermocycler at $37{ }^{\circ} \mathrm{C}$, and an aliquot $(8 \mu \mathrm{L})$ from each well was then added to PBS (392 $\mu \mathrm{L}$, Invitrogen, Grand Island, NY) containing BSA $(0.10 \mathrm{mg} / \mathrm{mL})$ and DTT $(5 \mathrm{mM})$. To quantitate the fluorescence change upon RI-binding, an aliquot $(100 \mu \mathrm{L})$ from the PBS dilution was transferred to a 96-well black non-binding surface polystyrene plate (Corning, Corning, NY). Data were converted to the fraction of RI oxidized by normalizing for the fluorescence of the unbound complex and were fitted to eq 2 to determine $\mathrm{IC}_{50}$ values. The fluorescence intensity of diethylfluorescein-labeled ribonucleases remained constant over the range of $\mathrm{H}_{2} \mathrm{O}_{2}$ concentrations used in the assay, indicating that any change observed was not due to an effect of $\mathrm{H}_{2} \mathrm{O}_{2}$ on the fluorophore or free ribonuclease.

$$
y=\frac{100 \%}{1+10^{\left(\log \left(\mathrm{IC}_{50} /\left[\mathrm{H}_{2} \mathrm{O}_{2}\right]\right)\right)^{h}}}
$$

\section{Sequence and Phylogenetic Analysis}

Sequence alignments of RI and ribonuclease (Figure 1 and Figures S-1-S-3) were performed with the program Clustal W (45). Cladograms of RI and ribonuclease were made with the program MegAlign in the Lasergene software package (DNASTAR, Madison, WI). Bootstrap values were calculated by using 2,000 replicates, and values $>40$ are reported. Accession codes for RI sequences used for alignment are Bos taurus (gi: 78369509), Rattus norvegicus (gi: 77416905), Mus musculus (gi: 78099143), Gallus gallus (gi: 57529989), Sus scrofa (gi: 1942101), Pan troglodytes (gi: 38503347), Homo sapiens (gi: 71042211). Accession codes for ribonuclease sequences used for alignment are Bos taurus brain (gi: 27806923), Bos taurus seminal (gi: 32441267), Bos taurus pancreatic (gi: 48429071), Rattus norvegicus (gi: 71361661), Mus musculus (gi: 133221), Gallus gallus (gi: 45383972), Sus scrofa (gi: 133225), Pan troglodytes (gi: 38503271), Homo sapiens (gi: 71042210).

\section{RESULTS}

With their large concave surface areas, the structural family of leucine-rich repeats (LRRs), for which RI is the prototype, is well-suited to recognize diverse ligands (Figure 1A) (46). Accordingly, RI has served as a structural model for protein-protein recognition (26). Multiple biological roles have been assigned to RI, including protecting cells from rogue ribonucleases and scavenging free radicals $(25,26,47,48)$. The latter activity is attributed to the 29-32 free cysteine residues found in RI, whose oxidation leads to irreversible inactivation of the protein $(44,49)$.

The amino-acid sequences of RIs from multiple organisms (Figure S-2) have been reported, and some of these proteins have been characterized (50-54). In 1980, bRI was isolated and found to inhibit ribonucleolytic activity (50). Its amino-acid sequence and biochemical characteristics were, however, not reported $(47,50)$. The amino-acid sequence of bRI (Figure 1B) was annotated in the GenBank registry as "Bos taurus similar to ribonuclease inhibitor" (gi: 78369509). The sequence of bRI was $74 \%$ identical to hRI (Figure S-1) and had the consensus A-Type and B-Type repeating architecture of RIs (Figure 1B) (26). bRI contains 29 of the 32 cysteine residues in $\mathrm{hRI}$ and was able to be produced and purified by a procedure identical to that used for hRI $(34,28)$, yielding $5 \mathrm{mg}$ of bRI per liter of $E$. coli culture. bRI, hRI, and their complexes with RNase A and RNase 1 were then analyzed to reveal environmental factors that influence complex-stability and thereby modulate the regulation of ribonucleolytic activity.

\section{Dissociation Rate for RI-Ribonuclease Complexes}

The RI-ribonuclease complex is one of the tightest known biological interactions $(27,55,28)$. The association rate constant for complex formation between $\mathrm{RI}$ and ribonucleases is close to 
the diffusion limit $\left(10^{9} \mathrm{M}^{-1} \mathrm{~s}^{-1}\right)(56,27,28)$, due to the strong electrostatic nature of the interaction $(57,28)$. Yet, the dissociation rate constants of the hRI-RNase 1 and hRI-RNase A complexes differ significantly, owing to differences in the hydrogen bonds and van der Waals contacts made between hRI and the two ribonucleases (28).

The dissociation rate constants for the complexes of bRI and hRI with RNase A and RNase 1 were determined by using a competition assay described previously $(27,28)$. The observed increase in fluorescence as the RI.ribonuclease complex dissociates is shown in Figure 2, and the $k_{\mathrm{d}}$ values determined by fitting the resulting data to eq 1 are listed in Table 1. Only the hRI-RNase A complex dissociated completely over the length of the experiment (Figure 2A) with a $t_{1 / 2}\left(=\ln 2 / k_{\mathrm{d}}\right)$ of $14 \mathrm{~h}$, which is nearly identical to the value determined previously (13 h) (27). All of the other RI-ribonuclease complexes were $<50 \%$ dissociated after 15 days (Figure 2). Their $k_{\mathrm{d}}$ values were within twofold of each other (Table 1) and their $t_{1 / 2}$ values (34 days for bRI-RNase A, 78 days for bRI-RNase 1, and 68 days for hRI-RNase 1) were within twofold of that for the hRI-angiogenin complex ( $t_{1 / 2}=60$ days) (27). The clustering of the $k_{\mathrm{d}}$ values of the most stable RI-ribonuclease complexes suggests that an upper limit for the halflives of the dissociation rate of an RI-ribonuclease complex has been reached at approximately three months (Table 1) (27).

By assuming that all of the complexes have association rate constants close to the diffusion limit (28), the equilibrium dissociation constants $\left(K_{\mathrm{d}}\right)$ of the complexes can be estimated. The $K_{\mathrm{d}}$ values for the bRI-RNase A, bRI-RNase 1 , and hRI-RNase 1 complexes are all in the range of 0.30-0.69 fM, whereas the hRI-RNase A complex has at least 50-fold lower stability (35 fM) (Table 1). Overall, both bRI and hRI are tight inhibitors of ribonucleases, but bRI binds more tightly to both human and bovine ribonucleases.

\section{Conformation and Conformational Stability}

Proteins are stabilized upon binding to small-molecule ligands (58-61) or with other proteins $(62,63)$. The magnitude of the stabilization is often related directly to the affinity of the protein for the ligand $(59,61,64)$. To determine whether the conformational stability of bRI and hRI increases upon complex formation and whether this increase correlates with complex-stability, the conformational stability of each RI-ribonuclease complex was determined by CD spectroscopy (Figure 3) $(40,61,65)$.

The far-UV CD spectra of free RI, free ribonuclease, and RI-ribonuclease complexes are depicted in Figures 3A and 3B. bRI and hRI have similar CD spectra, with minima at $222 \mathrm{~nm}$ being indicative of similar secondary structure and three-dimensional architecture (65). When complexed with a ribonuclease, the maxima of the CD spectra for hRI and bRI shift to $225 \mathrm{~nm}$. Complexes between RI and ribonuclease were formed with a slight molar excess of ribonuclease $(28 \mu \mathrm{M})$ to $\mathrm{RI}(25 \mu \mathrm{M})$ to ensure complete complex formation by RI and to allow accurate determination of the conformational stability of RI. The ellipticity of RI, which has a repeating $\alpha$-helix, $\beta$-strand architecture (Figure 1A), overwhelms the ellipticity of the ribonucleases (e.g., bRI: $[\theta]_{222 \mathrm{~nm}}=-14,000 \mathrm{deg} \cdot \mathrm{cm}^{2} \cdot \mathrm{dmol}^{-1}$; RNase A: $[\theta]_{222 \mathrm{~nm}}=-7,600$ $\mathrm{deg} \cdot \mathrm{cm}^{2} \cdot \mathrm{dmol}^{-1}$; Figures $3 \mathrm{~A}$ and $3 \mathrm{~B}$ ). Hence, changes in ellipticity report largely on changes to the conformation of RI.

The stability of the RI-ribonuclease complexes as a function of temperature is shown in Figures $3 \mathrm{C}$ and 3D. The mid-points of each transition curve $\left(T_{\mathrm{m}}\right)$ were obtained by fitting the data to a two-state model and are listed in Table 1 . Unbound $\mathrm{hRI}\left(T_{\mathrm{m}}=54^{\circ} \mathrm{C}\right)$ is slightly more stable than is unbound $\mathrm{bRI}\left(T_{\mathrm{m}}=51{ }^{\circ} \mathrm{C}\right)$, but bRI gains more stability upon forming a complex with either ribonuclease. The $T_{\mathrm{m}}$ values of both RIs increase by $>10^{\circ} \mathrm{C}$ upon complex formation with ribonuclease. The hRI-RNase A complex was the least stable of the four complexes, in accord with its having the largest dissociation rate constant (Figure 2). 


\section{Oxidative Stability}

With its 29-32 free cysteine residues and abundance in the cytosol, RI serves to mediate oxidative damage (48). RI scavenges reactive oxygen species such as superoxide anion, hydroxyl radical, and singlet oxygen with $\mathrm{IC}_{50}$ values below $10 \mu \mathrm{g} / \mathrm{mL}$, making it a powerful antioxidant (47). To investigate the oxidative stability of bRI and hRI and to determine how complex formation affects their oxidative stability, the vulnerability of both RIs to oxidation by $\mathrm{H}_{2} \mathrm{O}_{2}$ was tested $(38,44)$.

The binding curves obtained after incubating bRI, hRI, or RI-ribonuclease complexes with $\mathrm{H}_{2} \mathrm{O}_{2}$ are shown in Figure 4, and the $\mathrm{IC}_{50}$ values are listed in Table 1. The oxidative stability of $\mathrm{hRI}\left(\mathrm{IC}_{50}=0.017 \% \mathrm{v} / \mathrm{v} \mathrm{H}_{2} \mathrm{O}_{2}\right)$ was close to that measured previously by evaluating the inhibition of ribonucleolytic activity by $\mathrm{hRI}\left(0.007 \% \mathrm{v} / \mathrm{v} \mathrm{H}_{2} \mathrm{O}_{2}\right.$ (44)). The oxidative stability of bRI ( 29 cysteine residues; Figure 1B) was, however, 4-fold higher than that of hRI (32 cysteine residues). bRI has both of the adjacent cysteine pairs that were shown to be important to the oxidative resistance of hRI (44). Yet, native bRI has oxidative stability similar to that of previously characterized oxidation-resistant variants of hRI (Table 2) (44).

The decreased oxidative stability of hRI compared to bRI could be due to the replacement of three residues in bRI with cysteine in hRI (Figure 1). Two of these cysteine residues, Cys74 and Cys 408 (hRI numbering), were especially attractive candidates for decreasing the oxidative stability. The sulfur atoms of Cys 74 and Cys 29 are within $6 \AA$ and could form a destabilizing disulfide bond upon oxidation, as seen for adjacent free cysteine residues in hRI (44); Cys408 has the highest solvent accessible surface area of any cysteine residue in hRI, as calculated for chain Y from PDB accession code 1Z7X with the program POPS (66). Both Cys74 and Cys408 in hRI were replaced with the corresponding residues in bRI, C74L and C408G, and the oxidative stabilities of the resulting variants are shown in Figure 4C. C408G hRI appears to be more sensitive to oxidation, as its stability curve shows a steeper transition to the oxidized form. In the three-dimensional structure of the hRI-RNase 1 complex (28), Cys408 forms molecular contacts with Asn67 of RNase 1. As oxidative stability is measured in relation to RI-binding, substitution of Cys 408 with a glycine residue could weaken the affinity for RNase 1 , making hRI more susceptible to rapid oxidation. Yet, C408G hRI $\left(\mathrm{IC}_{50}=(0.023 \pm 0.002) \%\right.$ $\mathrm{v} / \mathrm{v}_{2} \mathrm{O}_{2}$ ) still has near identical oxidative stability to wild-type hRI, whereas C74L hRI $\left(\mathrm{IC}_{50}=(0.043 \pm 0.005) \% \mathrm{v} / \mathrm{v} \mathrm{H}_{2} \mathrm{O}_{2}\right)$ has 2.5 -fold higher oxidative stability than wild-type hRI, putting its stability within twofold of that of bRI (Table 1). Thus, the existence of a cysteine residue at position 74 in $\mathrm{hRI}$ is responsible for the additional sensitivity of hRI to oxidation and could represent an adaptive substitution that diminishes RI concentration at a lower cytosolic reduction potential.

Upon complex formation with RNase A, bRI gains an additional 4-fold in oxidative stability and remains stably bound to RNase $A$ at up to $0.30 \% \mathrm{v} / \mathrm{v} \mathrm{H}_{2} \mathrm{O}_{2}\left(0.13 \mathrm{M} \mathrm{H}_{2} \mathrm{O}_{2}\right)$, again underscoring the extraordinary stability of the RI-ribonuclease complex. Surprisingly, complex formation with RNase 1 elicits a twofold decrease in the oxidative stability of bRI. This decrease could be due to changes in the bRI structure upon RNase 1 binding, as seen upon RNase A binding to porcine RI (29), allowing better access to reactive sulfhydryl groups. Additionally, RNase 1, being more cationic than RNase A (67), could preferentially shift the $\mathrm{p} K_{\mathrm{a}}$ of nearby cysteine residues (38), thereby favoring the transition from the thiol (RSH) to the more reactive thiolate $\left(\mathrm{RS}^{-}\right)$form $(68,69)$ and facilitating disulfide bond formation $(44)$. $\mathrm{hRI}$, in contrast, has slightly increased oxidative stability upon complex formation with either RNase A or RNase 1 (Table 1). Overall, the oxidative stability of RI-ribonuclease complexes seems to mirror their conformational stability. 


\section{DISCUSSION}

Unregulated ribonucleolytic activity is potentially damaging to essential cellular processes $(12,13,15,70)$. To protect themselves, cells have evolved RI $(25,26,31)$. RI might have coevolved with its ribonuclease ligands (26,31), as mammalian RIs do not bind to ribonuclease homologues from frogs $(71,72)$ and hRI has 100 -fold higher affinity for human RNase 1 than for bovine RNase A (28). This relationship is not definitive, however, as two of three new ribonucleases identified from fish (Danio rerio) are bound by hRI (23).

The structural basis of the possible co-evolution of ribonucleases and RI (Figure 1A) has been elucidated at atomic resolution for four RNase A superfamily members: RNase A, angiogenin (RNase 5), eosinophil-derived neurotoxin (RNase 2), and RNase 1 (28-30, 73, 74). The structural contacts within the hRI-RNase 1 complex (PDB accession code 1Z7X) were extracted and the conservation of these RI residues are compared in Table 2 (28). If RI and ribonuclease have co-evolved, contact residues are likely to be conserved between RI proteins. For example, bRI and chicken RI have amino-acid sequence identities to hRI of 74 and 49\%, respectively (Figure S-1), but for contact residues, the sequence identities to hRI are 93 and $61 \%$, respectively (Table 2). The greater conservation of contact residues is consistent with the existence of selective pressure that maintains the high affinity of RI for ribonucleases. Also, a phylogenetic tree of these RI proteins from diverse organisms (Figure 5A) has an architecture and rate of evolution similar to that of the phylogenetic tree of ribonucleases from the same organisms (Figure 5B) (52-54). To gain insight into the co-evolution of affinity of this femtomolar protein-protein complex and to address whether an evolutionary imperative exists for species-specific regulation of ribonucleolytic activity, RI from cow and human were produced in E. coli and purified along with their cognate ribonucleases.

The binding of proteins to small ligands can increase the thermal stability of the protein through the influence of the ligand on the unfolding equilibrium of the protein $(58,59,61,64)$. The increase in thermal stability $\left(\Delta T_{\mathrm{m}}\right)$ can be related directly to the binding affinity $\left(K_{\mathrm{d}}\right)$ of ligands for the protein (75), but only when the association rate and binding enthalpy of the ligands are constant (64). These same principles of thermal stabilization can also be applied to protein protein complexes $(62,63)$. Both RI and ribonuclease are stabilized upon formation of a RI-ribonuclease complex (Table 1). All of the complexes between bRI or hRI and ribonuclease have $\Delta T_{\mathrm{m}}>10^{\circ} \mathrm{C}$ from free RI, with the bRI-RNase A complex having the largest change at $17-18^{\circ} \mathrm{C}$. This $\Delta T_{\mathrm{m}}$ value is similar to that for barstar upon complex formation with barnase $\left(\Delta T_{\mathrm{m}}=20^{\circ} \mathrm{C}(63)\right)$, its cognate ribonuclease. Like the binding of vertebrate

ribonucleases by RI, the binding of barnase by barstar is essential to cell survival (76). Thus, all known essential ribonuclease inhibitor-ribonuclease interactions have a $\Delta T_{\mathrm{m}}$ value in the range of $10-20^{\circ} \mathrm{C}$.

For RI-ribonuclease complexes, $\Delta T_{\mathrm{m}}$ should serve as a good indicator of binding affinity (64, 75 ), as the association rates and binding enthalpies for RNase 1 and RNase A should be nearly identical (28). The dissociation rate constants and $\Delta T_{\mathrm{m}}$ for RI-ribonuclease complexes do indeed correlate, as the hRI.RNase A complex has the fastest dissociation rate and the lowest $\Delta T_{\mathrm{m}}\left(10^{\circ} \mathrm{C}\right)$, and as both bRI-ribonuclease complexes have identical $k_{\mathrm{d}}$ values and $\Delta T_{\mathrm{m}}$ values (Table 1). This direct relationship between binding affinity and thermal stability suggests that the thermal stability of RI.ribonuclease complexes could be used in future studies to estimate their binding affinities.

Besides acting as an intracellular sentry, RI appears to play another biological role. The natural abundance of cysteine residues is $1.7 \%$ (77). In contrast, $6-7 \%$ of the residues in known RIs are cysteine. The 29-32 cysteine residues of RI are able to contribute to the regulation of cellular redox homeostasis by scavenging free radicals $(47,48,78)$. The ensuing oxidation of the 
cysteine residues to half-cystines leads to the rapid degradation of RI in the cell (78). In primates, RI seems to have evolved greater sensitivity to oxidation through the addition of a specific cysteine residue, Cys74 (Figure 4C), whose conversion to leucine increases the oxidative stability of hRI by 2.5 -fold. This increased sensitivity of hRI to oxidation could facilitate greater regulation of the cellular concentration of hRI through modulation of the cellular redox environment and thus permit more sensitive control over ribonuclease biology.

Upon formation of a complex with an intraspecies ribonuclease, the oxidative stability of RI increases (Table 1 and Figure 4), compromising its ability to compensate for oxidative stress. Apparently, the two biological roles of RI are functionally distinct, but its role in inhibiting invading ribonucleases appears to supersede its role in mediating oxidative damage, as even under extreme oxidative stress (e.g., $0.13 \mathrm{M} \mathrm{H}_{2} \mathrm{O}_{2}$ for the bRI-RNase A complex), it remains bound to ribonucleases. Other cellular biomolecules can serve to regulate the cellular redox environment (79), but no other cellular inhibitors of ribonucleases are known (26). Consequently, RI needs to maintain its high affinity for ribonucleases so as to protect cellular RNA, even under severely oxidizing conditions $(12,13,15)$.

The kinetic inhibition of ribonucleases by RI is essentially permanent, as both bRI and hRI bind RNase A and RNase 1 with $K_{\mathrm{d}}$ values that are below $30 \mathrm{fM}$ and with $t_{1 / 2}$ values for the complexes (except the hRI-RNase A complex) that extend beyond 5 weeks (Table 1). Interestingly, bRI does not show the same species-specific affinity preference of hRI (28). Rather, bRI maintains broader specificity for ribonucleases (Table 1 and Figure 2) and greater oxidative stability than hRI (Figure 4). Cows have more ribonucleases (20 (22)) than do humans (13 (21)), including three with high similarity to RNase 1 from three different tissues (Figure 5B). Accordingly, bRI might need to maintain broader specificity so as to recognize more ribonucleases. Additionally, the biological role of RNase A is to digest dietary RNA in a cow stomach (80), but new biological roles for RNase 1 in vertebrates seem to be evolving, as bursts of gene duplication and gene deactivation are observed in Carnivora (81). hRI might be evolving new biological roles along with RNase 1 and adding new levels of cellular regulation through its sensitivity to oxidative stress. Addressing these evolutionary questions will require the purification and identification of RI proteins from additional organisms, and performing analyses similar to those performed for ribonucleases $(17,18,21,22,82)$.

\section{Conclusions}

The complexes between RI and ribonucleases serve as an ideal model system to investigate the co-evolution of an essentially permanent protein-protein complex. To protect cells from damaging ribonucleolytic activity, the RI-ribonuclease complex remains intact even when confronted by severe thermal or oxidative stress. Yet, hRI shows increased sensitivity to oxidation (largely due to Cys74) than does bRI, suggesting greater regulation of the cellular concentration of hRI through modulation of the cellular redox environment. hRI also displays greater variation in binding affinity for ribonucleases, as it binds RNase 1 with significantly higher affinity than RNase A, whereas bRI maintains broader specificity, binding both ribonucleases with high affinity.

\section{Supplementary Material}

Refer to Web version on PubMed Central for supplementary material.

\section{Acknowledgements}

We are grateful to D. R. McCaslin for assistance with CD spectroscopy, and to T. J. Rutkoski and G.A. Ellis for assistance with RI purification. 


\section{References}

1. Gavin AC, Bosche M, Krause R, Grandi P, Marzioch M, Bauer A, Schultz J, Rick JM, Michon AM, Cruciat CM, Remor M, Hofert C, Schelder M, Brajenovic M, Ruffner H, Merino A, Klein K, Hudak M, Dickson D, Rudi T, Gnau V, Bauch A, Bastuck S, Huhse B, Leutwein C, Heurtier MA, Copley RR, Edelmann A, Querfurth E, Rybin V, Drewes G, Raida M, Bouwmeester T, Bork P, Seraphin B, Kuster B, Neubauer G, Superti-Furga G. Functional organization of the yeast proteome by systematic analysis of protein complexes. Nature 2002;415:141-147. [PubMed: 11805826]

2. Ho Y, Gruhler A, Heilbut A, Bader GD, Moore L, Adams SL, Millar A, Taylor P, Bennett K, Boutilier K, Yang L, Wolting C, Donaldson I, Schandorff S, Shewnarane J, Vo M, Taggart J, Goudreault M, Muskat B, Alfarano C, Dewar D, Lin Z, Michalickova K, Willems AR, Sassi H, Nielsen PA, Rasmussen KJ, Andersen JR, Johansen LE, Hansen LH, Jespersen H, Podtelejnikov A, Nielsen E, Crawford J, Poulsen V, Sorensen BD, Matthiesen J, Hendrickson RC, Gleeson F, Pawson T, Moran MF, Durocher D, Mann M, Hogue CW, Figeys D, Tyers M. Systematic identification of protein complexes in Saccharomyces cerevisiae by mass spectrometry. Nature 2002;415:180-183. [PubMed: 11805837]

3. Krogan NJ, Cagney G, Yu H, Zhong G, Guo X, Ignatchenko A, Li J, Pu S, Datta N, Tikuisis AP, Punna T, Peregrin-Alvarez JM, Shales M, Zhang X, Davey M, Robinson MD, Paccanaro A, Bray JE, Sheung A, Beattie B, Richards DP, Canadien V, Lalev A, Mena F, Wong P, Starostine A, Canete MM, Vlasblom J, Wu S, Orsi C, Collins SR, Chandran S, Haw R, Rilstone JJ, Gandi K, Thompson NJ, Musso G, StOnge P, Ghanny S, Lam MH, Butland G, Altaf-Ul AM, Kanaya S, Shilatifard A, O'Shea E, Weissman JS, Ingles CJ, Hughes TR, Parkinson J, Gerstein M, Wodak SJ, Emili A, Greenblatt JF. Global landscape of protein complexes in the yeast Saccharomyces cerevisiae. Nature 2006;440:637643. [PubMed: 16554755]

4. Fraser HB, Hirsh AE, Steinmetz LM, Scharfe C, Feldman MW. Evolutionary rate in the protein interaction network. Science 2002;296:750-752. [PubMed: 11976460]

5. Lemos B, Meiklejohn CD, Hartl DL. Regulatory evolution across the protein interaction network. Nat Genet 2004;36:1059-1060. [PubMed: 15378060]

6. Hahn MW, Kern AD. Comparative genomics of centrality and essentiality in three eukaryotic proteininteraction networks. Mol Biol Evol 2005;22:803-806. [PubMed: 15616139]

7. Mintseris J, Weng Z. Structure, function, and evolution of transient and obligate protein-protein interactions. Proc Natl Acad Sci USA 2005;102:10930-10935. [PubMed: 16043700]

8. Saeed R, Deane CM. Protein-protein interactions, evolutionary rate, abundance and age. BMC Bioinformatics 2006;7:128. [PubMed: 16533385]

9. Liao BY, Scott NM, Zhang J. Impacts of gene essentiality, expression pattern, and gene compactness on the evolutionary rate of mammalian proteins. Mol Biol Evol 2006;23:2072-2080. [PubMed: 16887903]

10. He X, Zhang J. Why do hubs tend to be essential in protein networks? PLoS Genet 2006;2:e88. [PubMed: 16751849]

11. Nooren IM, Thornton JM. Diversity of protein-protein interactions. EMBO J 2003;22:3486-3492. [PubMed: 12853464]

12. Raines RT. Ribonuclease A. Chem Rev 1998;98:1045-1065. [PubMed: 11848924]

13. Leland PA, Schultz LW, Kim BM, Raines RT. Ribonuclease A variants with potent cytotoxic activity. Proc Natl Acad Sci USA 1998;98:10407-10412. [PubMed: 9724716]

14. Leland PA, Raines RT. Cancer chemotherapy_ribonucleases to the rescue. Chem Biol 2001;8:405413. [PubMed: 11358688]

15. Smith BD, Raines RT. Genetic selection for critical residues in ribonucleases. J Mol Biol 2006;362:459-478. [PubMed: 16920150]

16. Beintema JJ. Structure, properties and molecular evolution of pancreatic-type ribonucleases. Life Chem Rep 1987;4:333-389.

17. Beintema JJ, Schüller C, Irie M, Carsana A. Molecular evolution of the ribonuclease superfamily. Prog Biophys Molec Biol 1988;51:165-192. [PubMed: 3074337] 
18. Beintema, JJ.; Breukelman, HJ.; Carsana, A.; Furia, A. Evolution of vertebrate ribonucleases: Ribonuclease A superfamily. In: D’Alessio, G.; Riordan, JF., editors. Ribonucleases: Structures and Functions. Academic Press; New York: 1997. p. 245-269.

19. Zhang J, Rosenberg HF, Nei M. Positive Darwinian selection after gene duplication in primate ribonuclease genes. Proc Natl Acad Sci USA 1998;95:3708-3713. [PubMed: 9520431]

20. Singhania NA, Dyer KD, Zhang J, Deming MS, Bonville CA, Domachowske JB, Rosenberg HF. Rapid evolution of the ribonuclease A superfamily: Adaptive expansion of independent gene clusters in rats and mice. J Mol Evol 1999;49:721-728. [PubMed: 10594173]

21. Cho S, Beintema JJ, Zhang J. The ribonuclease A superfamily of mammals and birds: Identifying new members and tracing evolutionary histories. Genomics 2005;85:208-220. [PubMed: 15676279]

22. Cho S, Zhang J. Ancient expansion of the ribonuclease A superfamily revealed by genomic analysis of placental and marsupial mammals. Gene 2006;373:116-125. [PubMed: 16530354]

23. Pizzo E, Buonanno P, Di Maro A, Ponticelli S, De Falco S, Quarto N, Cubellis MV, D' Alessio G. Ribonucleases and angiogenins from fish. J Biol Chem 2006;281:27454-27460. [PubMed: 16861230]

24. Nitto T, Dyer KD, Czapiga M, Rosenberg HF. Evolution and function of leukocyte RNase A ribonucleases of the avian species, Gallus gallus. J Biol Chem 2006;281:25622-25634. [PubMed: 16803891]

25. Haigis MC, Kurten EL, Raines RT. Ribonuclease inhibitor as an intracellular sentry. Nucleic Acids Res 2003;31:1024-1032. [PubMed: 12560499]

26. Dickson KA, Haigis MC, Raines RT. Ribonuclease inhibitor: Structure and function. Prog Nucleic Acid Res Mol Biol 2005;80:349-374. [PubMed: 16164979]

27. Lee FS, Shapiro R, Vallee BL. Tight-binding inhibition of angiogenin and ribonuclease A by placental ribonuclease inhibitor. Biochemistry 1989;28:225-230. [PubMed: 2706246]

28. Johnson RJ, McCoy JG, Bingman CA, Phillips GN, Raines RT. Inhibition of human pancreatic ribonuclease by the human ribonuclease inhibitor protein. J Mol Biol 2007;368:434-449. [PubMed: 17350650]

29. Kobe B, Deisenhofer J. A structural basis of the interactions between leucine-rich repeats and protein ligands. Nature 1995;374:183-186. [PubMed: 7877692]

30. Kobe B, Deisenhofer J. Mechanism of ribonuclease inhibition by ribonuclease inhibitor protein based on the crystal structure of its complex with ribonuclease A. J Mol Biol 1996;264:1028-1043. [PubMed: 9000628]

31. Haigis MC, Haag ES, Raines RT. Evolution of ribonuclease inhibitor protein by exon duplication. Mol Biol Evol 2002;19:960-964.

32. Smith BD, Soellner MB, Raines RT. Potent inhibition of ribonuclease A by oligo(vinylsulfonic acid). J Biol Chem 2003;278:20934-20938. [PubMed: 12649287]

33. Rutkoski TJ, Kurten EL, Mitchell JC, Raines RT. Disruption of shape-complementarity markers to create cytotoxic variants of ribonuclease A. J Mol Biol 2005;354:41-54. [PubMed: 16188273]

34. Klink TA, Vicentini AM, Hofsteenge J, Raines RT. High-level soluble production and characterization of porcine ribonuclease inhibitor. Protein Expr Purif 2001;22:174-179. [PubMed: 11437592]

35. Lavis LD, Chao TY, Raines RT. Fluorogenic label for biomolecular imaging. ACS Chem Biol 2006;1:252-260. [PubMed: 17163679]

36. Abel RL, Haigis MC, Park C, Raines RT. Fluorescence assay for the binding of ribonuclease A to the ribonuclease inhibitor protein. Anal Biochem 2002;306:100-107. [PubMed: 12069420]

37. Riddles PW, Blakeley RL, Zerner B. Reassessment of Ellman's reagent. Methods Enzymol 1983;91:49-60. [PubMed: 6855597]

38. Lavis LD, Rutkoski TJ, Raines RT. Tuning the $\mathrm{p} K_{\mathrm{a}}$ of fluorescein to optimize binding assays. Anal Chem 2007;79:6755-6782.

39. Leland PA, Staniszewski KE, Park C, Kelemen BR, Raines RT. The ribonucleolytic activity of angiogenin. Biochemistry 2002;41:1343-1350. [PubMed: 11802736]

40. Johnson RJ, Lin SR, Raines RT. A ribonuclease zymogen activated by the NS3 protease of the hepatitis C virus. FEBS J 2006;273:5457-5465. [PubMed: 17116245] 
41. Johnson RJ, Lin SR, Raines RT. Genetic selection to reveal the role of a buried, conserved polar residue. Protein Sci 2007;16:1609-1616. [PubMed: 17656580]

42. Pace CN. Measuring and increasing protein stability. Trends Biotechnol 1990;8:93-98. [PubMed: 1367432]

43. Pace CN, Hebert EJ, Shaw KL, Schell D, Both V, Krajcikova D, Sevcik J, Wilson KS, Dauter Z, Hartley RW, Grimsley GR. Conformational stability and thermodynamics of folding of ribonucleases Sa, Sa2 and Sa3. J Mol Biol 1998;279:271-286. [PubMed: 9636716]

44. Kim BM, Schultz LW, Raines RT. Variants of ribonuclease inhibitor that resist oxidation. Protein Sci 1999;8:430-434. [PubMed: 10048337]

45. Chenna R, Sugawara H, Koike T, Lopez R, Gibson TJ, Higgins DG, Thompson JD. Multiple sequence alignment with the Clustal series of programs. Nucleic Acids Res 2003;31:3497-3500. [PubMed: 12824352]

46. McEwan PA, Scott PG, Bishop PN, Bella J. Structural correlations in the family of small leucinerich repeat proteins and proteoglycans. J Struct Biol 2006;155:294-305. [PubMed: 16884925]

47. Wang S, Li H. Radical scavenging activity of ribonuclease inhibitor from cow placenta. Biochemistry (Moscow) 2006;71:520-524. [PubMed: 16732730]

48. Monti DM, Montesano Gesualdi N, Matoušek J, Esposito F, D’Alessio G. The cytosolic ribonuclease inhibitor contributes to intracellular redox homeostasis. FEBS Lett 2007;581:930-934. [PubMed: 17292889]

49. Park C, Raines RT. Adjacent cysteine residues as a redox switch. Protein Eng 2001;14:939-942. [PubMed: 11742114]

50. Burton LE, Blackburn P, Moore S. Ribonuclease inhibitor from bovine brain. Int J Pept Protein Res 1980;16:359-364. [PubMed: 7216611]

51. Burton LE, Fucci NP. Ribonuclease inhibitors from the livers of five mammalian species. Int J Pept Protein Res 1982;19:372-379. [PubMed: 7118407]

52. Hofsteenge J, Kieffer B, Matthies R, Hemmings BA, Stone SR. Amino acid sequence of the ribonuclease inhibitor from porcine liver reveals the presence of leucine-rich repeats. Biochemistry 1988;27:8537-8544. [PubMed: 3219361]

53. Lee FS, Fox EA, Zhou H-M, Strydom DJ, Vallee BL. Primary structure of human placental ribonuclease inhibitor. Biochemistry 1988;27:8545-8553. [PubMed: 3219362]

54. Kawanomoto M, Motojima K, Sasaki M, Hattori H, Goto S. cDNA cloning and sequence of rat ribonuclease inhibitor, and tissue distribution of mRNA. Biochim Biophys Acta 1992;1129:335-338. [PubMed: 1536887]

55. Teufel DP, Kao RY, Acharya KR, Shapiro R. Mutational analysis of the complex of human RNase inhibitor and human eosinophil-derived neurotoxin (RNase 2). Biochemistry 2003;42:1451-1459. [PubMed: 12578357]

56. Stone SR, Hofsteenge J. Kinetics of the inhibition of thrombin by hirudin. Biochemistry 1986;25:4622-4628. [PubMed: 3768302]

57. Shaul Y, Schreiber G. Exploring the charge space of protein-protein association: a proteomic study. Proteins 2005;60:341-352. [PubMed: 15887221]

58. Sturtevant JM. Biochemical applications of differential scanning calorimetry. Annu Rev Phys Chem 1987;38:463-488.

59. Brandts JF, Lin LN. Study of strong to ultratight protein interactions using differential scanning calorimetry. Biochemistry 1990;29:6927-6940. [PubMed: 2204424]

60. Hytönen VP, Nyholm TK, Pentikäinen OT, Vaarno J, Porkka EJ, Nordlund HR, Johnson MS, Slotte JP, Laitinen OH, Kulomaa MS. Chicken avidin-related protein 4/5 shows superior thermal stability when compared with avidin while retaining high affinity to biotin. J Biol Chem 2004;279:93379343. [PubMed: 14660583]

61. Mayhood TW, Windsor WT. Ligand binding affinity determined by temperature-dependent circular dichroism: Cyclin-dependent kinase 2 inhibitors. Anal Biochem 2005;345:187-197. [PubMed: 16140252]

62. Donovan JW, Beardslee RA. Heat stabilization produced by protein-protein association. A differential scanning calorimetric study of the heat denaturation of the trypsin-soybean trypsin 
inhibitor and trypsin-ovomucoid complexes. J Biol Chem 1975;250:1966-1971. [PubMed: 1167859]

63. Makarov AA, Protasevich II, Lobachov VM, Kirpichnikov MP, Yakovlev GI, Gilli RM, Briand CM, Hartley RW. Thermostability of the barnase-barstar complex. FEBS Lett 1994;354:251-254. [PubMed: 7957933]

64. Waldron TT, Murphy KP. Stabilization of proteins by ligand binding: Application to drug screening and determination of unfolding energetics. Biochemistry 2003;42:5058-5064. [PubMed: 12718549]

65. Kelly SM, Jess TJ, Price NC. How to study proteins by circular dichroism. Biochim Biophys Acta 2005;1751:119-139. [PubMed: 16027053]

66. Cavallo L, Kleinjung J, Fraternali F. POPS: A fast algorithm for solvent accessible surface areas at atomic and residue level. Nucleic Acids Res 2003;31:3364-3366. [PubMed: 12824328]

67. Johnson RJ, Chao T-Y, Lavis LD, Raines RT. Cytotoxic ribonucleases: The dichotomy of Coulombic forces. Biochemistry 2007;46:10xxx-10xxx.

68. Szajewski RP, Whitesides GM. Rate constants and equilibrium constants for thiol-disulfide interchange reactions involving oxidized glutathione. J Am Chem Soc 1980;102:2011-2026.

69. Shaked Z, Szajewski RP, Whitesides GM. Rates of thiol-disulfide interchange reactions involving proteins and kinetic measurements of thiol $\mathrm{p} K_{\mathrm{a}}$ values. Biochemistry 1980;19:4156-4166. [PubMed: 6251863]

70. Leland PA, Staniszewski KE, Kim BM, Raines RT. Endowing human pancreatic ribonuclease with toxicity for cancer cells. J Biol Chem 2001;276:43095-43102. [PubMed: 11555655]

71. Tomita Y, Goto Y, Okazaki T, Shukuya R. Liver ribonucleases from the bullfrog, Rana catesbeiana. Purification, properties and changes in activity during metamorphosis. Biochim Biophys Acta 1979;562:504-514. [PubMed: 313217]

72. Wu Y, Mikulski SM, Ardelt W, Rybak SM, Youle RJ. A cytotoxic ribonuclease. J Biol Chem 1993;268:10686-10693. [PubMed: 8486718]

73. Papageorgiou A, Shapiro R, Acharya K. Molecular recognition of human angiogenin by placental ribonuclease inhibitor—an X-ray crystallographic study at 2.0 Å resolution. EMBO J 1997;16:51625177. [PubMed: 9311977]

74. Iyer S, Holloway DE, Kumar K, Shapiro R, Acharya KR. Molecular recognition of human eosinophilderived neurotoxin (RNase 2) by placental ribonuclease inhibitor. J Mol Biol 2005;347:637-655. [PubMed: 15755456]

75. Matulis D, Kranz JK, Salemme FR, Todd MJ. Thermodynamic stability of carbonic anhydrase: Measurements of binding affinity and stoichiometry using ThermoFluor. Biochemistry 2005;44:5258-5266. [PubMed: 15794662]

76. Hartley RW. Barnase and barstar: Two small proteins to fold and fit together. Trends Biochem Sci 1989;14:450-454. [PubMed: 2696173]

77. McCaldon P, Argos P. Oligopeptide biases in protein sequences and their use in predicting protein coding regions in nucleotide sequences. Proteins 1988;4:99-122. [PubMed: 3227018]

78. Blázuez M, Fominaya JM, Hofsteenge J. Oxidation of sulfhydryl groups of ribonuclease inhibitor in epithelial cells is sufficient for its intracellular degradation. J Biol Chem 1996;271:18638-18642. [PubMed: 8702516]

79. Valko M, Rhodes CJ, Moncol J, Izakovic M, Mazur M. Free radicals, metals and antioxidants in oxidative stress-induced cancer. Chem Biol Interact 2006;160:1-40. [PubMed: 16430879]

80. Barnard EA. Biological function of pancreatic ribonuclease. Nature 1969;221:340-344. [PubMed: 4974403]

81. Yu L, Zhang YP. The unusual adaptive expansion of pancreatic ribonuclease gene in carnivora. Mol Biol Evol 2006;23:2326-2335. [PubMed: 16950759]

82. Beintema JJ, Hofsteenge J, Iwama M, Morita T, Ohgi K, Irie M, Sugiyama RH, Schieven GL, Dekker CA, Glitz DG. Amino acid sequence of the nonsecretory ribonuclease of human urine. Biochemistry 1988;27:4530-4538. [PubMed: 3166997] 
A

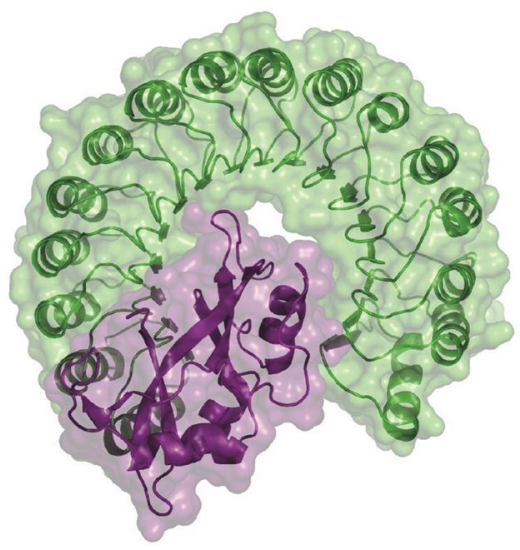

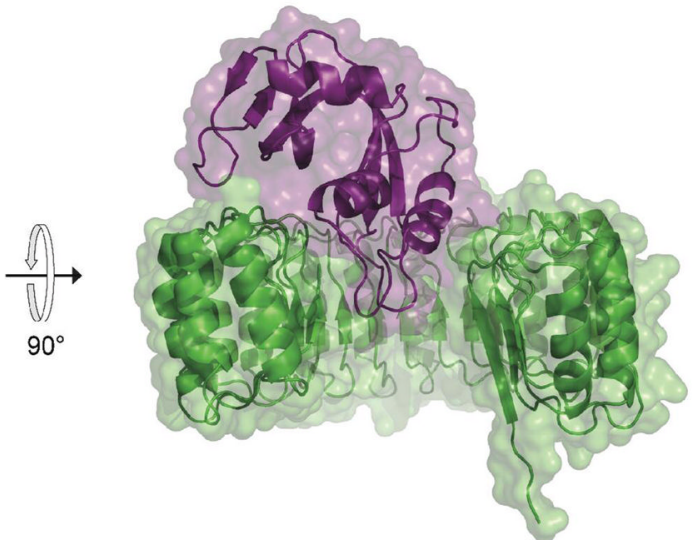

B-Type Repeat
B

consensus

bovine $\mathrm{RI}$
human $\mathrm{RI}$

bovine R

human $\mathrm{R}$

bovine $\mathrm{R}$
human $\mathrm{R}$

bovine

human $\mathrm{F}$

bovine

human RI

bovine $\mathrm{R}$
human $\mathrm{F}$

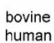

bovine
human

bovine $F$

bovine RI
human $\mathrm{R}$
f

A-Type Repeat

$X L X X L X L X X C X L T X X X C X X L X X A L X X X X X L X E L X L X X N X L G D X G A X X L C X G L X X P X X$

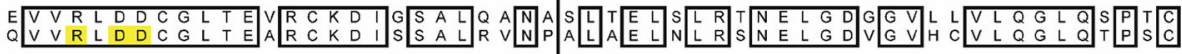

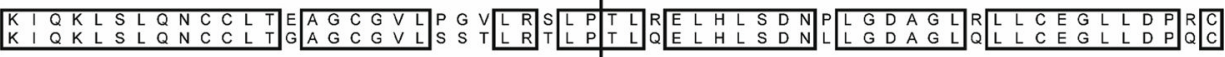

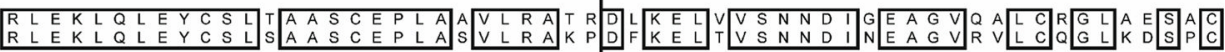

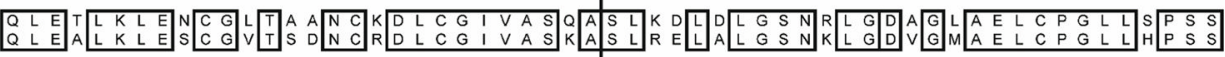
0
$R$

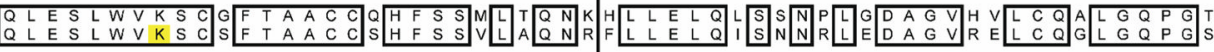

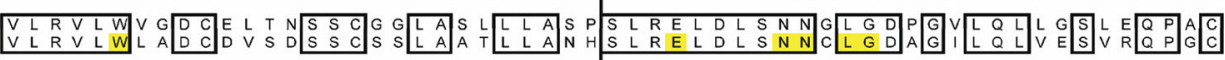

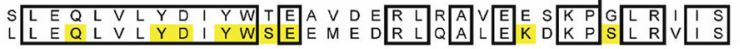

Figure 1.

Structure and sequence of RI. (A) Ribbon diagram of the hRI (green). RNase 1 (purple) complex (chains $\mathrm{Y}$ and $\mathrm{Z}$ from PDB accession code 1Z7X) (28). Images were made with the program PyMOL (DeLano Scientific, South San Francisco, CA). (B) Sequence alignment of the protein sequences of bRI and hRI. Conserved amino acids are shown with black boxes and contact residues $(<3.9 \AA$ ) within the hRI-RNase 1 complex are shaded yellow (chains $\mathrm{Y}$ and $\mathrm{Z}$ from PDB accession code 1Z7X) (28). Alignments were performed with the program Clustal W (45). Consensus sequences for A-Type and B-Type repeats of RI-like LRRs were adapted from ref (26). 
A

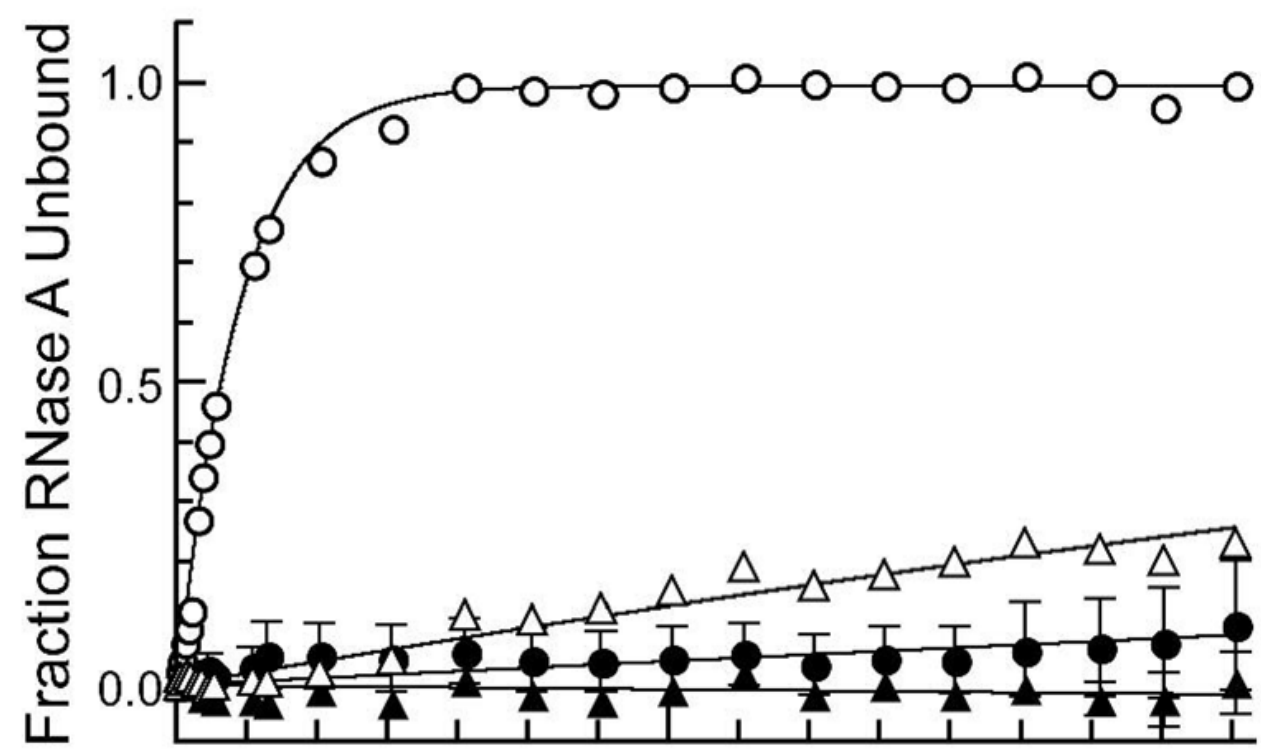

B

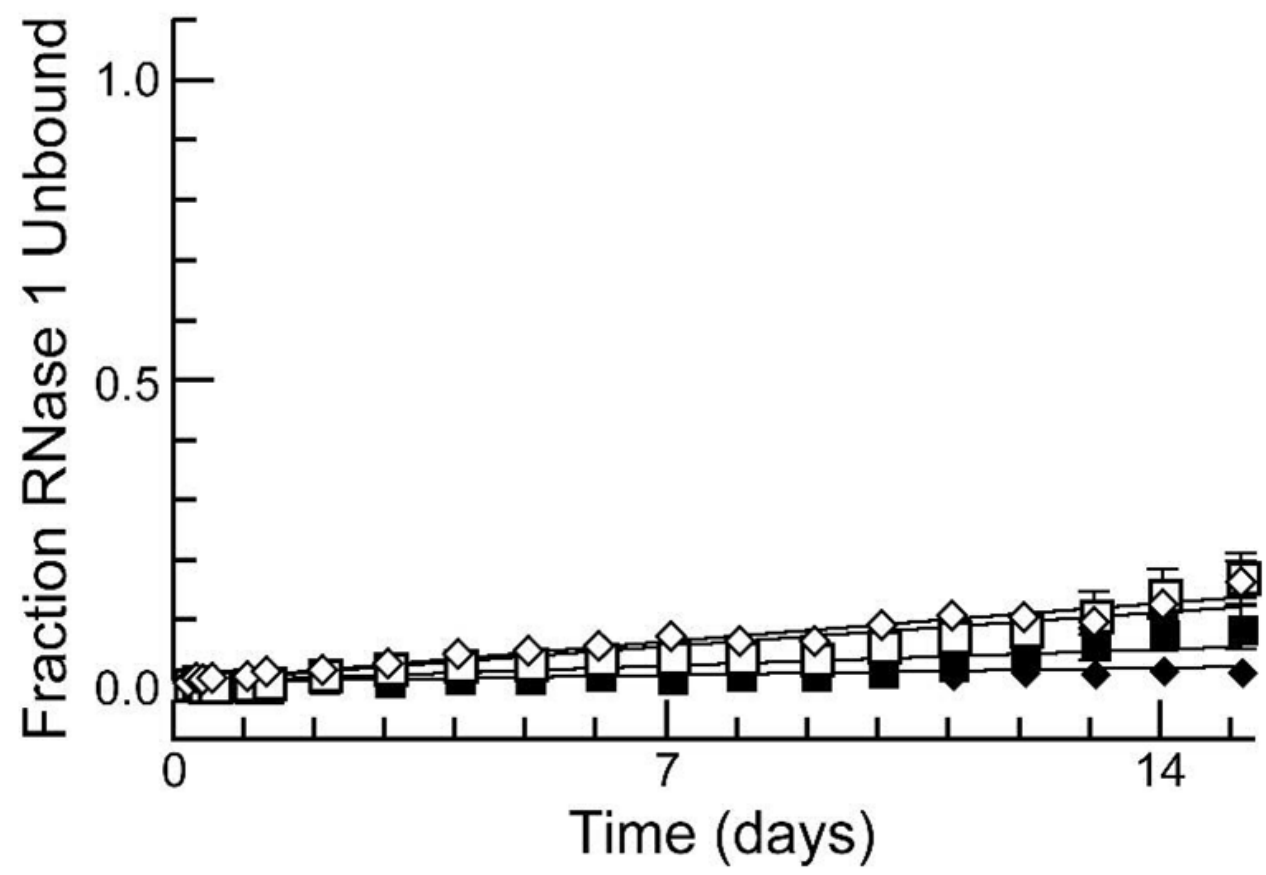

Figure 2.

Dissociation of RI-ribonuclease complexes. The release of diethylfluorescein-labeled ribonuclease $(100 \mathrm{nM})$ from $\mathrm{RI}(100 \mathrm{nM})$ was followed over time after the addition of a 50fold molar excess of angiogenin $(5 \mu \mathrm{M})$ (open symbols) or after the addition of PBS (closed symbols). Data points are the mean $( \pm \mathrm{SE})$ of six separate measurements and are normalized for both the average fluorescence of rhodamine $110(10 \mathrm{nM})$ and the fluorescence of unbound RNase A from hRI-RNase A. The initial fluorescence of unbound ribonuclease was used as the end-point for complete ribonuclease release (28). (A) Dissociation of bRI RNase A $(\Delta)$ and hRI·RNase A (०); (B) Dissociation of bRI·RNase 1 ( $\square$ ) and hRI·RNase $1(\diamond)$. 

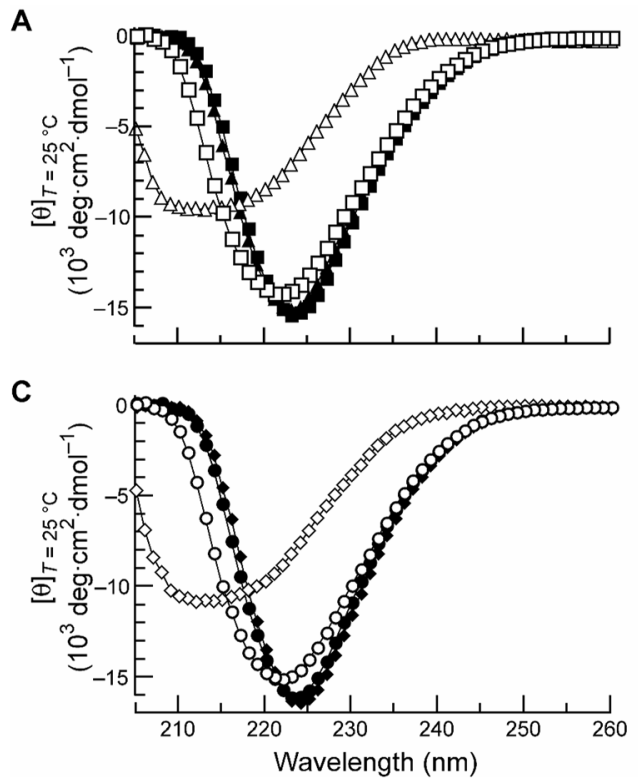

B

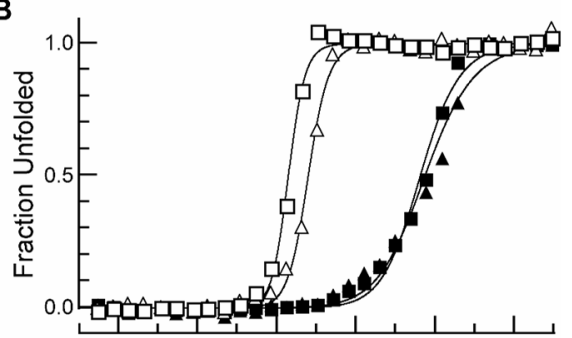

D

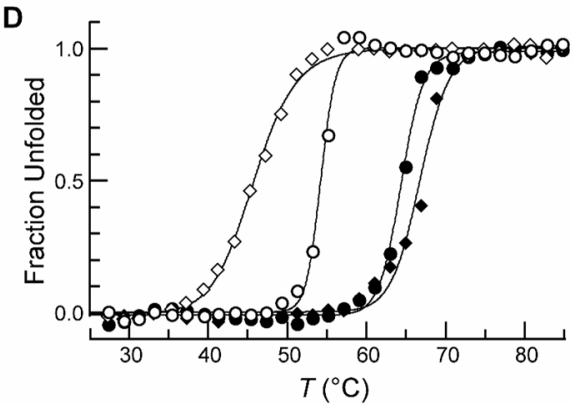

Figure 3.

Conformation and conformational stability of RI-ribonuclease complexes. (A and C) Far-UV CD spectra of RI, ribonuclease, and RI-ribonuclease complexes $(25 \mu \mathrm{M}$ RI and $28 \mu \mathrm{M}$ ribonuclease in PBS containing DTT $(2 \mathrm{mM})$ ). (B and D) Thermal denaturation of RI, ribonuclease, and RI-ribonuclease complexes $(25 \mu \mathrm{M}$ RI and $28 \mu \mathrm{M}$ ribonuclease in PBS containing DTT (2 mM)). Molar ellipticity at $222 \mathrm{~nm}$ was monitored after a 2 -min equilibration at each temperature. Data were fitted to a two-state model to determine values for $T_{\mathrm{m}}$ (Table 1) $(42,43)$. Panels A and B depict data for RNase A $(\Delta)$, bRI $(\square)$, bRI·RNase A $(\boldsymbol{\Delta})$, and bRI·RNase $1(\boldsymbol{\square})$; panels $\mathrm{C}$ and D depict data for RNase $1(\diamond)$, hRI (०), hRI·RNase $1(\diamond)$, and hRI·RNase A (•). 

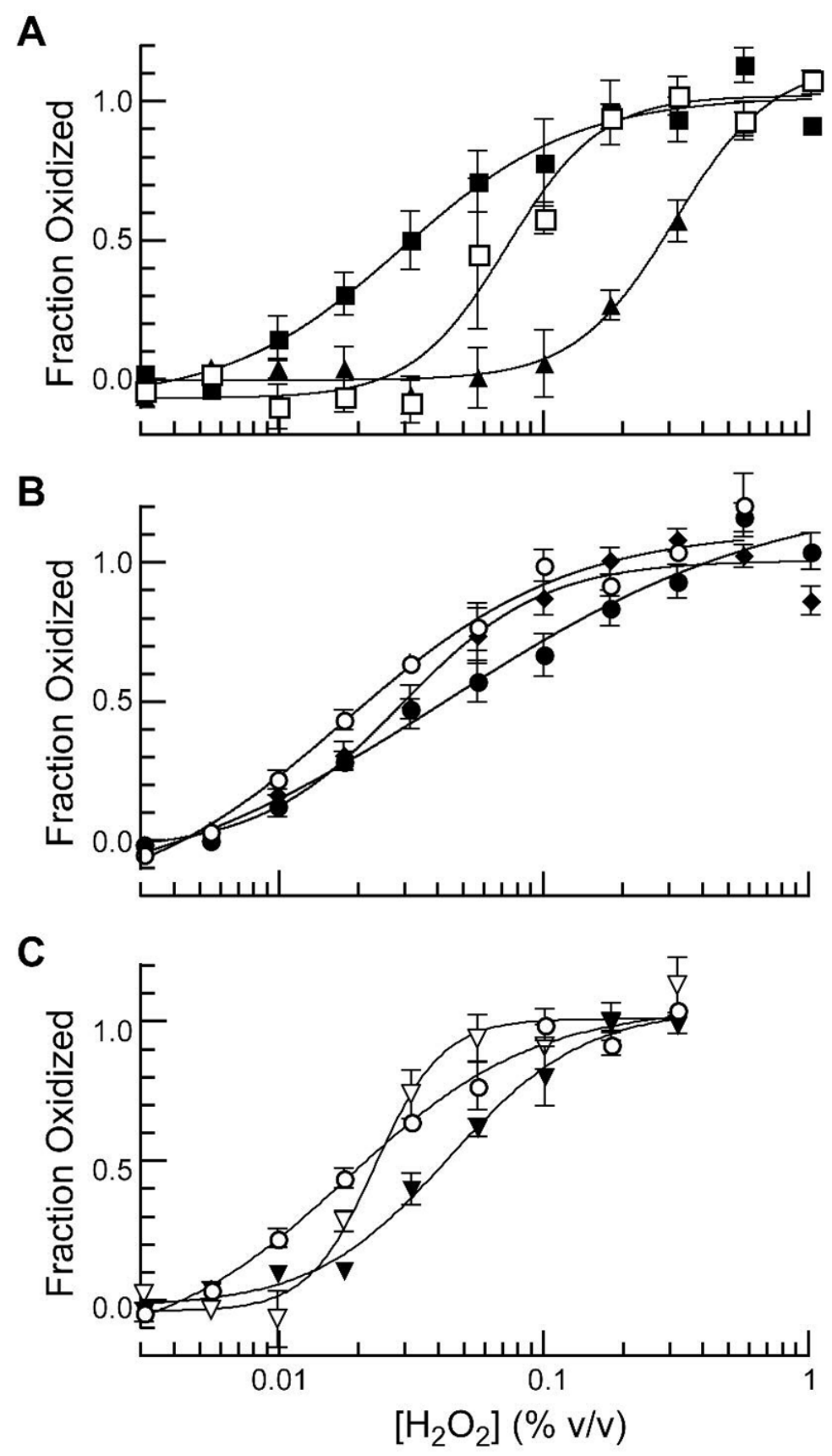

Figure 4.

Stability to hydrogen peroxide oxidation $\left(\mathrm{H}_{2} \mathrm{O}_{2}\right)$ of RI and RI-ribonuclease complexes. The decrease in fluorescence intensity of diethylfluorescein-labeled ribonuclease upon binding to RI was used to measure the oxidative stability of free RI and RI-ribonuclease complexes (44, $36,38)$. The complex formed by $\mathrm{RI}(10 \mu \mathrm{M})$ and ribonuclease $(10 \mu \mathrm{M})$ was incubated in serial dilutions of $\mathrm{H}_{2} \mathrm{O}_{2}$ buffered in $20 \mathrm{mM}$ HEPES- $\mathrm{HCl}$ buffer, $\mathrm{pH} 7.6$, containing $\mathrm{KCl}(50 \mathrm{mM})$ and DTT $(\leq 50 \mu \mathrm{M})$ for $30 \mathrm{~min}$ at $37^{\circ} \mathrm{C}$. Data points are the mean $( \pm \mathrm{SE})$ of three independent experiments and were normalized for the maximum fluorescence of the unbound ribonuclease. Data were fitted to eq 2 to determine values of $\mathrm{IC}_{50}$ (Table 1). Panel A depicts data for bRI $(\square)$, bRI·RNase A ( $\mathbf{\Delta})$, and bRI·RNase $1(\boldsymbol{\square})$; panel B depicts data for hRI (०), hRI·RNase 1 
$(\diamond)$, and hRI-RNase A (•); panel C depicts data for hRI (०), C74L hRI ( $\nabla)$, and C408G hRI $(\nabla)$. 
A

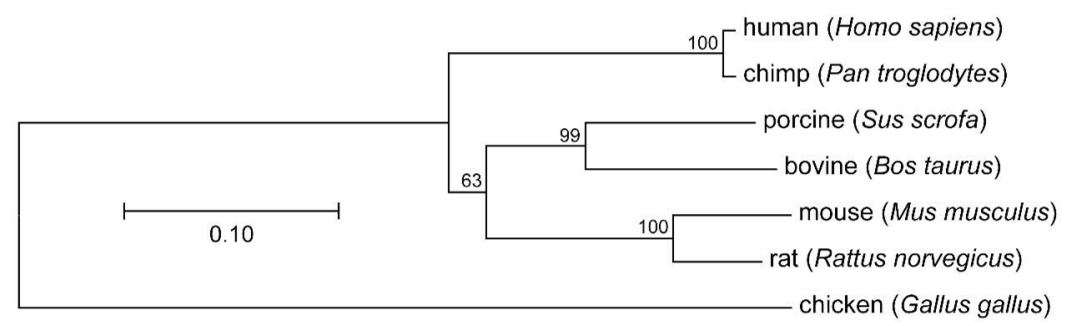

B

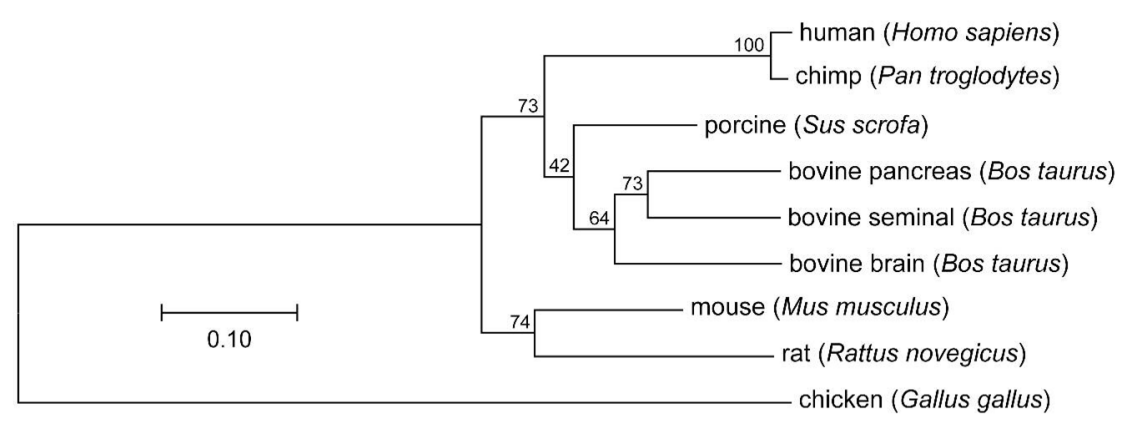

Figure 5.

Phylogenetic tree of RIs (A) and ribonucleases (B) from various organisms. Cladograms of RI and ribonuclease were made with the program MegAlign from the Lasergene software package (DNASTAR, Madison, WI). Bootstrap values were calculated using 2,000 replicates, and values $>40$ are reported. The bar indicates the distance for 0.10 substitutions per site. GenBank accession codes for RI and ribonuclease sequences are listed in the experimental procedures, and sequence alignments are shown in Figures S-2 and S-3. 
Table 1

Biochemical parameters for bRI, hRI, and RI·ribonuclease complexes.

\begin{tabular}{|c|c|c|c|c|}
\hline & $k_{\mathrm{d}}\left(10^{-7} \mathrm{~s}^{-1}\right)^{a}$ & $K_{\mathrm{d}}(\mathrm{fM})^{b}$ & $T_{\mathrm{m}}\left({ }^{\circ} \mathbf{C}\right)^{c}$ & $\mathrm{IC}_{50}\left(\% \mathrm{v} / \mathrm{v} \mathrm{H}_{2} \mathrm{O}_{2}\right) \mathrm{d}$ \\
\hline $\begin{array}{l}\text { bRI } \\
\text { bRI-RNase A } \\
\text { bRI-RNase } 1\end{array}$ & $\begin{array}{c}-\overline{-} \\
2.36 \pm 0.05 \\
1.03 \pm 0.07\end{array}$ & $\begin{array}{l}\overline{0.69} \\
0.30\end{array}$ & $\begin{array}{l}51.3 \pm 0.1 \\
68.6 \pm 0.3 \\
68.0 \pm 0.2\end{array}$ & $\begin{array}{c}0.071 \pm 0.010 \\
0.30 \pm 0.004 \\
0.029 \pm 0.008\end{array}$ \\
\hline $\begin{array}{l}\text { hRI } \\
\text { hRI-RNase A } \\
\text { hRI.RNase } 1\end{array}$ & $\begin{array}{c}-\overline{119 \pm 2} \\
1.17 \pm 0.05\end{array}$ & $\begin{array}{l}-\overline{-} \\
35 \\
0.34\end{array}$ & $\begin{array}{l}54.1 \pm 0.1 \\
64.2 \pm 0.1 \\
66.6 \pm 0.2\end{array}$ & $\begin{array}{l}0.017 \pm 0.004 \\
0.042 \pm 0.016 \\
0.028 \pm 0.004\end{array}$ \\
\hline
\end{tabular}

${ }^{a}$ Values of $k_{\mathrm{d}}( \pm \mathrm{SE})$ were determined by following the release of diethylfluorescein-labeled ribonuclease from the RI-ribonuclease complex over time and fitting the resulting data to eq 1 .

${ }^{b}$ Values of $K_{\mathrm{d}}( \pm \mathrm{SE})$ were calculated using the relationship $K_{\mathrm{d}}=k_{\mathrm{d}} / k_{\mathrm{a}}$ and the $k_{\mathrm{a}}$ value for hRI + RNase A (27).

${ }^{c}$ Values of $T_{\mathrm{m}}( \pm \mathrm{SE})$ were determined by CD spectroscopy in PBS containing DTT $(2 \mathrm{mM})$.

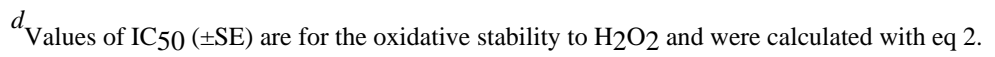




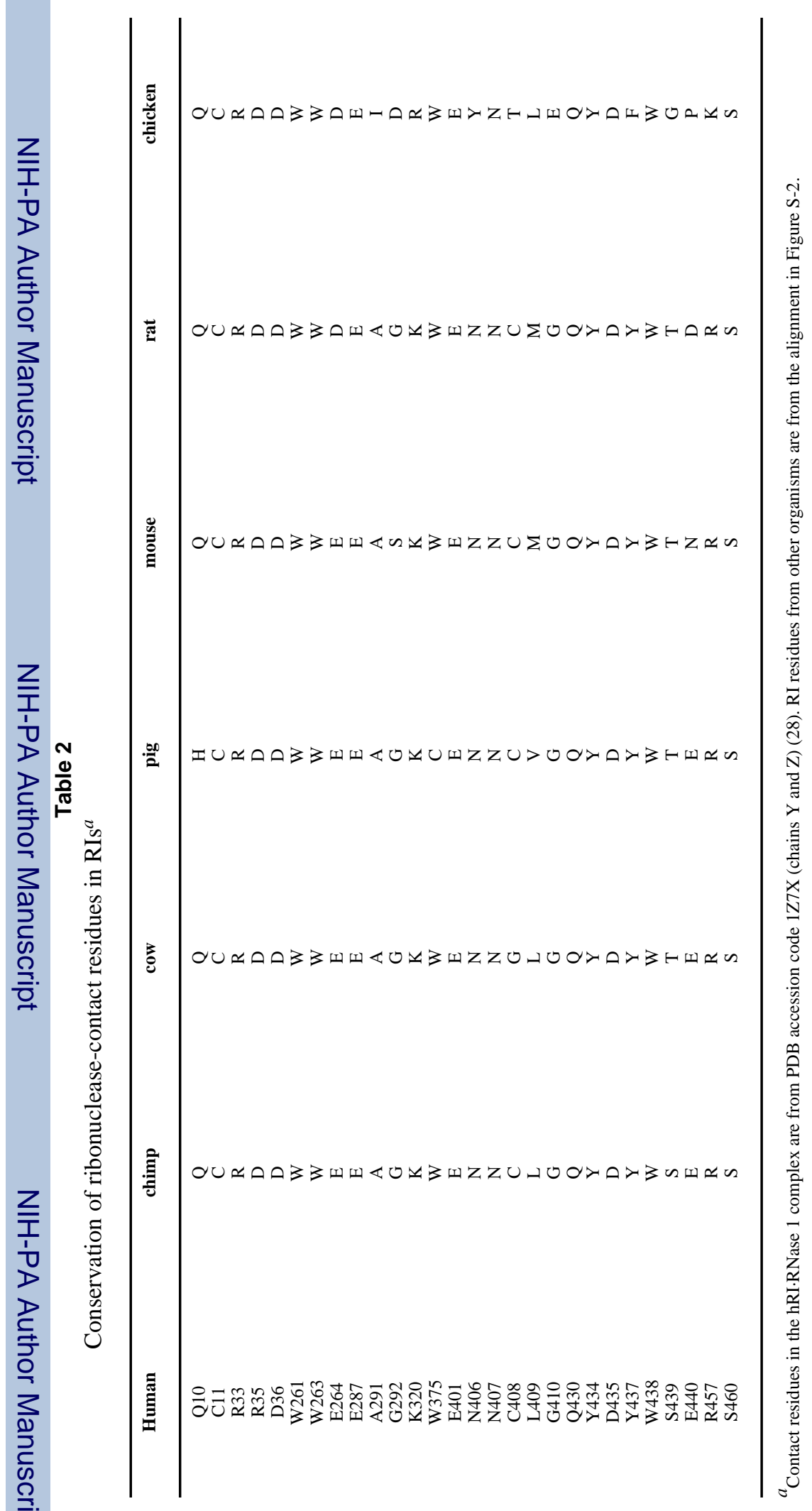

